\title{
Sensory properties of oriental melon (Cucumis melo var. makuwa) by quantitative descriptive analysis and consumer test
}

\author{
Sang Seop Kim, Eun Jeong Choi, Jeong Hee Choi, Kyung Hyung $\mathrm{Ku}^{*}$ \\ Food Distributuion System Research Group, Korea Food Research Institute, Seongnam 13539, Korea
}

\section{묘사분석 및 소비자 조사에 의한 참외의 관능특성}

\author{
김상섭·최은정·최정희 · 구경형* \\ 한국식품연구원 저장유통연구단
}

\begin{abstract}
This study was carried out to determine the descriptive sensory profile of oriental melon. The sensory profile of oriental melons (cultivated in Seonju, Kyungsangbuk-do) were used quantitative descriptive analyses and twelve trained panel developed the total forty sensory attributes related appearance, aroma, texture etc. Six appearances attributes and two aromas attributes were derived from whole oriental melon with skin. Five aromas, six tastes and six textures were derived from the mesocarp of oriental melon. And also, oriental melons were analyzed for pH, titratable acidity, solid soluble contents and weight. The weight, titratable acidity and soluble solid content of oriental melons showed significant differences according to samples. And also, in the sensory attributes of these samples by trained panel and consumer test, there were significant differences between organic cultivated samples and conventional cultivated samples. Based on principal component analysis of sensory attributes data by trained panel and consumer, oriental melons were primary separated along the first principal component, which accounted for $\mathbf{2 7 . 7 3 \%}$ (trained panel test) and $\mathbf{1 9 . 8 2} \%$ (consumer test) of total variance (trained panel test; $\mathbf{5 8 . 3 6} \%$, consumer test; 46.18\%) between the samples farm, cultivation method, total acidity, sweet aroma, bittemess, etc. Generally, whole oriental melon with skin showed significant differences in the sensory attributes according to cultivation method and farms. But, the mesocarp and endocarp part showed not certainly differences in the sensory attributes between organic cultivated samples except conventional cultivated samples.
\end{abstract}

Key words : oriental melon, sensory profile, quantitative descriptive analysis, cultivation method

\section{서 론}

참외(Cucumis melo var. makuwa)는 박과류에 속하는 1년 생 식물로 분류학적으로는 멜론(Cucumis melo)의 한 변종 이고 원산지는 아프리카 사하라 남부, 중국, 이란, 터키, 인도 등이라고 알려져 있다. 한국에는 삼국시대 또는 그 이전 중국의 화북으로부터 들어 온 것으로 추측되는데 외

*Corresponding author. E-mail : khku@kfri.re.kr Phone : 82-31-780-9052, Fax : 82-31-709-9876

Received 3 May 2016; Revised 13 June 2016; Accepted 22 June 2016.

Copyright (C) The Korean Society of Food Preservation. All rights reserved.
(瓜), 첨과(甛瓜), 참외(眞瓜), 왕과(王瓜), 띠외(土瓜), 쥐참외 (野甛瓜) 등의 다양한 명칭으로 불리어진다 $(1,2)$. 참외의 국 내 주요 생산지는 경상북도 성주군으로 재배 면적 3,953 $\mathrm{ha}$, 연간 약 143,271 톤으로 전국 참외 생산량의 $68 \%$ 를 차지 하는 최대 주산지이다(1). 최근 참외는 여름철의 대표적인 과일에서 재배 기술의 발전으로 연중 생산되어 소비자에게 공급되고 있고, 일본, 홍콩, 대만, 싱가폴 등에 수출이 되고 있다. 참외에는 다른 과채류와 비교하여 비타민 $\mathrm{A}$ 와 $\mathrm{C}$ 가 풍부하고 참외에 함유되어 있는 유리당 성분인 glucose와 fructose는 피로 회복에 도움을 주고 꼭지 부분의 쓴맛을 내는 cucurbitacin은 항암성분으로 한방에서 참외 꼭지를 건조해서 진해, 거담, 변비, 황달 등의 치료제나 급성 위장 염, 중풍 등에도 효과가 있는 것으로 알려져 있다 $(3,4)$. 
최근 식품 안전과 관련된 사건들은 소비자들의 안전성에 대한 관심이 높아지게 되어 세계적으로 농산물의 안전성과 건강을 추구하는 친환경 농산물의 생산과 수요가 증가하고 있다. 특히 소득 수준이 높은 북미, 유럽 및 일본 등의 지역 을 중심으로 지속적인 성장세를 보이고 있다(5). 국내의 경우 친환경 농산물 인증 실적 조사 결과에 따르면 친환경 인증 농가수가 2000년 2,448호에서 2011년 160,628호로 약 65배 증가하였고, 인증 면적도 2000년 2,039 ha에서 2011년 172,674 ha로 약 84배, 생산량은 2000년 35,406톤에서 2011 년 1,819,228톤으로 약 50.4배 증가하였다. 2011년 기준 친 환경 농산물 시장 규모는 채소류가 약 9,364 억원으로 전체 유통 규모의 $28.7 \%$ 를 차지하고 있다(6).

한편 참외에 대한 연구로는 성주 지역 참외 바이러스병 의 발생실태와 전염 생태(1)와 참외를 포함한 국내 유통 농산물의 잔류 농약 모니터링, 친환경 실천 농가의 생산성 변화 분석 등( 7,8$)$ 이 보고되어 있다. 참외 가공과 활용에 관한 연구로는 참외 주스의 제조, 유산균을 이용한 참외 발효 식품의 제조, 전처리 방법에 따른 건조 참외의 품질 조건 설정에 관한 연구, 저급 참외의 효율적 활용 방안 연구 등과 MA포장 기법에 의한 참외의 신선도 유지에 관한 연구 (9-15)가 있다. 이외에 참외·멜론의 품종 분류 및 명명에 관한 연구(2), 참외 비식용 부위의 항산화 활성에 관한 연구, 참외 와인의 항산화능에 대한 연구 분야도 보고(16-19) 되 었다. 그러나 양질의 과채류 생산을 유도하기 위하여 소비 자의 객관적인 기호도를 반영한 품질 등급 기준에 관한 연구는 시작 단계에 있고 특히 소비자의 품질 지표와 관련 된 관능적 특성 연구는 거의 없는 실정이다 $(20,21)$.

본 연구는 성주에서 재배되는 참외의 정량적 묘사 분석 에 의한 관능 특성 개발과 친환경 재배인 유기농 참외와 관행 재배 참외의 관능적 특성 분석과 이화학적인 품질 지표와의 상관관계를 분석하여 친환경 참외의 품질 등급 기준 설정 및 수출을 위한 기초 자료로 이용하고자 수행되 었다.

\section{재료 및 방법}

\section{시 료}

본 실험에 사용된 참외는 경상북도 성주군에 위치한 농 가에서 친환경 재배 참외(Cucumis melo var. makuwa)을 2015년 5월 중순 적숙기에 수확하여 선과 과정을 거치지 않고 $20 \mathrm{~kg}$ 단위로 포장한 참외를 농가당 약 80 100 kg을 제 공받아 $1^{\circ} \mathrm{C}$ 저장고에서 유지하면서 실험에 사용하였다. 참외 시료는 상주에 위치한 유기농 참외 농가에서 재배한 시료와 관행재배 참외 시료는 2015년 5월에 수확된 성주산 참외를 서울 가락동 시장 공판장에서 구매하여 사용하였 다. 이화학적 특성과 관능적 품질 특성 분석을 위해 제공
받은 각 시료군마다 혼합한 후 비교적 크기가 비슷한 참외 를 선별한 후 개당 윗면과 아랫면으로 반절을 나누어 윗부 분은 이화학적 품질 특성 분석에 사용하고, 아랫면은 관능 검사 시료로 이용하였다.

\section{크기, 고형분 함량, $\mathrm{pH}$ 및 적정산도}

참외의 크기는 Volscan Profiler(Stable Micro System Ltd., Vienna Court, UK)로 참외를 횡으로 참외 꼭지 부분까지 부피와 무게를 측정하였다. 이때 조건은 참외 표면에 상처 가 나지 않도록 고무핀을 사용하였고, vertical step $15 \mathrm{~mm}$, rotation speed $1.0 \mathrm{rps}$ 이었다. 가용성 고형분 함량(soluble solid content)은 참외시료를 blender로 균질화한 후 거즈로 여과한 추출액을 디지털 당도계(N-1E, Atago, Tokyo, Japan)를 이용하여 각 처리구당 5 회 반복하여 평균값을 구 하였다. $\mathrm{pH}$ 는 참외 시료를 blender로 균질화한 액을 거즈로 여과하여 얻은 추출액 $3 \mathrm{~mL}$ 와 증류수 $27 \mathrm{~mL}$ 를 섞어 총량이 $30 \mathrm{~mL}$ 가 되게 한 후 $\mathrm{pH}$ meter(827, Metrohm, Zfinyen, Switzerland)를 측정하였다. 적정 산도는 추출액 $3 \mathrm{~mL}$ 와 증류수 $27 \mathrm{~mL}$ 를 혼합하여 $0.1 \mathrm{~N} \mathrm{NaOH}$ 용액으로 $\mathrm{pH}$ 가 8.3 이 될 때까지 적정하여 소비된 $0.01 \mathrm{~N} \mathrm{NaOH}$ 용액 소비량 을 구한 후 citric acid로 환산하여 표시하였다(24). 이때 분석 에 사용된 시료는 시료군당 관능검사에서 사용되었던 시료 중 10 개씩 취하여 3 번 반복 실험을 하였다.

\section{정량적 묘사 분석}

묘사 용어 도출과 표준 지표 개발을 위한 패널은 원내 게시판을 이용하여 모집을 하였으며, 이때 훈련을 받지 않 은 한국식품연구원에 근무하고 있는 연구원 30명중 맛 차 이에 예민한 패널 요원을 선정하기 위하여 4 가지 기본맛(단 맛, 짠맛, 신맛, 쓴맛)에 대한 기본 맛 인지 검사 및 순위 검사를 실시하였다. 지원한 패널원 중 정답률이 $75 \%$ 이상 이며, 평소 참외에 대한 구매력 및 지속적으로 본 실험에 참여 의사와 표현 능력 등을 고려하여 12 명을 패널 요원으 로 선정하였다(23). 참외의 묘사 분석을 위한 패널 훈련 과정은 관능적 특성을 도출하는 묘사 용어 개발 단계와 도출된 각각의 묘사 용어의 표준 시료를 확립하는 단계로 나누어 3 주간 훈련하였다. 또 본 실험은 확립된 묘사 용어를 이용하여 친환경 재배 참외와 관행재배 참외에 대한 관능적 특성 강도를 9점법으로 평가하였다. 이때 묘사 용어 개발과 훈련에 사용한 시료는 친환경 재배 5 개 농가에서 수집한 참외와 동일지역에서 관행으로 재배한 참외 1 종류를 한 개씩 제시하였다. 본 실험의 시료 제시는 수평으로 반절한 참외의 절단부위에서 $1 \mathrm{~cm}$ 두께로 자른 후 연구원내 관능평 가 부스를 이용하여, 불완전 블록법으로 계획하여 시료당 6번 평가하도록 하였다. 이때 사용한 시료된 총 시료는 각 시료구당 72 개 시료로 총 432개 시료를 평가하였다. 한편 본 실험에서 각 시료의 관능적 특성 강도를 평가할 때에는 
훈련에서 확립한 표준 시료 및 그 강도를 제시하여 각 시료 에 대한 정확도를 유도하였으며 관능적 특성 용어 및 표준 시료와 강도 척도는 Table 1 과 같았다. 둔화 효과를 제어하 기 위해 한 회의 세션당 평가 시료는 4 종으로 한정하였다.

각 특성의 평가는 껍질을 제거하지 않은 참외의 외관, 향을 평가한 후 껍질 제거후의 참외 껍질 가까운 과육 (mesocarp)의 색, 전체 참외 대비 과육의 비율, 껍질 근처의 과육의 초록색 정도, 참외 씨 부분(endocarp)의 색, 과육과 씨와의 붙어 잇는 강도 씨방의 크기, 씨의 크기순으로 진행 되었으며, 과육(mesocarp)과 씨부분(endocarp)의 향과 맛, 조직감 및 후미의 순으로 평가하게 하였다. 색 강도는 패널 요원간의 토의를 통하여 참외 표면 색 평가 시 1 점에 해당하 는 점은 color guide(pantone solid chips uncoated)에서 120C, 9점에 해당하는 시료는 $7549 \mathrm{C}$ 로 색이 진해질수록 높은 점 수로 평가하게 하였고, 참외 껍질과 가까운 과육의 색 평가 시 1점에 해당하는 점은 color guide에 373, 9점에 해당하는 시료는 $7741 \mathrm{C}$ 다. 시료의 냄새는 세게 들이마셔 냄새를 맡은 후 평가하게 하였고, 맛은 껍질을 제거한 내과피를 먹었을 때의 맛을 평가하였으며, 한 시료를 평가한 후에는 약 30초 간의 휴식 시간을 취하게 하였다. 사용한 척도는 9점법을 이용하였으며, 1 점은 해당 특성이 없다는 것을 나타내고 점수가 높아질수록 특성 강도가 강해지는 것으로 평가하게 하였다.

\section{소비자검사}

일반 소비자는 일반 소비자를 대상으로 시료 6 개 군을 한 번에 평가하도록 하였고, 조사 항목은 참외의 전문패널 원에 의한 정량적 묘사분석 결과 유의적인 차이가 있고 일반 소비자도 쉽게 판단할 수 있는 항목 만을 선발하여 30 40대 소비자 100 명을 대상으로 실시하였다. 이때 소비 자에게 제공된 시료는 정량적 묘사 분석과 동일하게 수평으 로 반절한 참외의 절단부위에서 $1 \mathrm{~cm}$ 두께로 자른 후 연구 원내 관능평가 부스를 이용하여 조사하였다. 소비자 군의 분포는 30 대는 47 명, 50 대 53명이었고, 성별은 남 18 명, 여성 82 명이었고, 각 시료군당 100 개씩 총 600 개의 시료를 평가하게 하였다.

\section{통계분석}

유기농 재배 참외 및 관행 재배 참외의 이화학적 및 관능 적 품질 차이를 파악하기 위해 SAS for Windows 7.2(SAS Institute, Cary, NC, USA)을 사용하여 분산분석(analysis of variance)을 수행하였으며 Duncan's multiple range test를 통해 각 시료간의 유의적 차이를 검정하였다. 또 각 시료의 품질과 관능적 특성간의 관계를 요약하여 나타내기 위해서 XLSTAT ver. 2007.1(Addinsoft, NY, USA)를 이용하여 요 인간의 주성분 분석(principle component analysis)을 실시하 였다.

\section{결과 및 고찰}

\section{묘사 분석을 통한 참외의 관능적 특성}

참외의 훈련과정에서 패널의 동의하에 결정된 평가 특성 은 총 40 개가 도출되었다(Table 1). 참외의 경우는 외과피, 중과피 및 내과피로 나누어 도출되었는데, 외과피에서 도 출된 특성(6개)으로 껍질의 색(노란색 강도), 흰줄무늬의 선명도, 흰줄무늬의 깊이, 흰줄무늬의 규칙성, 껍질 손상정 도 및 크기였고, 향 특성(2개)은 고유한 참외의 냄새와 단향 이었다. 중과피의 외관 특성(3개)은 외과피와 가까운 중과 피의 투명도, 중과피의 비율, 외과피와 인접한 중과피의 초록색 강도가 도출되었고, 내과피(endocarp) 외관 특성(4 개)의 경우는 내과피의 투명도, 중과피와 내과피의 부착정 도, 내과피 씨부분의 분리 정도, 내과피 중심의 색, 씨의 크기가 도출되었다. 중과피의 향 특성(5개)은 단향, 고유한 참외향, 오이향, 무향, 풋내가 도출되었고, 내과피의 씨부분 의 특성(3개)은 단향, 참외향 및 과숙된 향이 도출되었다. 중과피의 맛 특성(7개)은 단맛, 고유한 참외 맛, 쓴맛, 오이 맛, 신맛, 과숙된 맛, 풋맛이 도출되었고, 조직감은 경도, 다즙성, 아삭함, 씨 함량, 씨의 경도, 가루끼 특성(6개)이 도출되었다. 또 후미로는 4 가지 특성(단맛, 떫은맛, 신맛, 아린맛)이 도출되었고, 각각의 특성 용어의 정의와 개념을 쉽게 인지시키기 위해 결정된 표준 물질은 Table 1 에 있다. 참외의 경우 관능적 특성 용어 도출에 관한 연구가 거의 없으나, Cucumis melo L 일종에 해당하는 Cantaloupe melon 의 경우 12 종의 향과 향미, 4 종의 맛과 2 종의 mouthfeel, 6종의 조직감 특성을 도출한 Bett-Garber 등(24)과 musk 멜론의 외관 특성 2 종, 향 6 종, 조직감 4 종, 향미 5 종을 도출 한 Vallone 등(25) 보다 많은 특성이 도출되었다. 본 연구에 서 도출된 관능 특성의 경우 멜론에서 도출된 특성보다는 많은 수의 관능 용어가 도출되었다. 이는 참외는 식물분류 학상으로 멜론과 동일하나 4000년 동안 아시아와 아프리카 지역에서 각각 독립적으로 변종들 간 자연 교잡에 의해 다양하게 변화되어 왔다는 $\mathrm{Yi}$ 등(1)의 연구와 멜론의 경우 내과피(씨가 있는 부분)을 거의 먹지 않는 반면 참외의 경우 소비자에 따라 내과피를 중과피와 함께 먹는 경우가 많아 참외와 멜론의 관능적 특성이 동일할 수 없고, 외과피, 중과 피 및 내과피로 나누어 관능특성을 도출하였기 때문에 많은 관능특성 항목이 도출 된 것으로 사료된다.

\section{재배 방법별 참외의 품질 특성 비교}

동일 지역에서 유기농으로 재배한 시료와 관행 재배한 참외의 이화학적 품질 및 전문 패널에 의한 묘사적 품질 특성은 Table 2 와 같다. 농가별 재배된 참외의 무게의 경우 $256.66 \pm 23.12 \sim 335.60 \pm 19.93 \mathrm{~g}$ 의 범위의 중량을 가졌고, 관 행 재배 참외 시료는 $283.48 \pm 9.58 \mathrm{~g}$ 이었다. $\mathrm{pH}$ 의 경우 유기 농 시료(OCI OCV)와 관행 재배 시료(CC)에 유의적인 차 
Table 1. Sensory attributes, definitions and physical standards for oriental melon

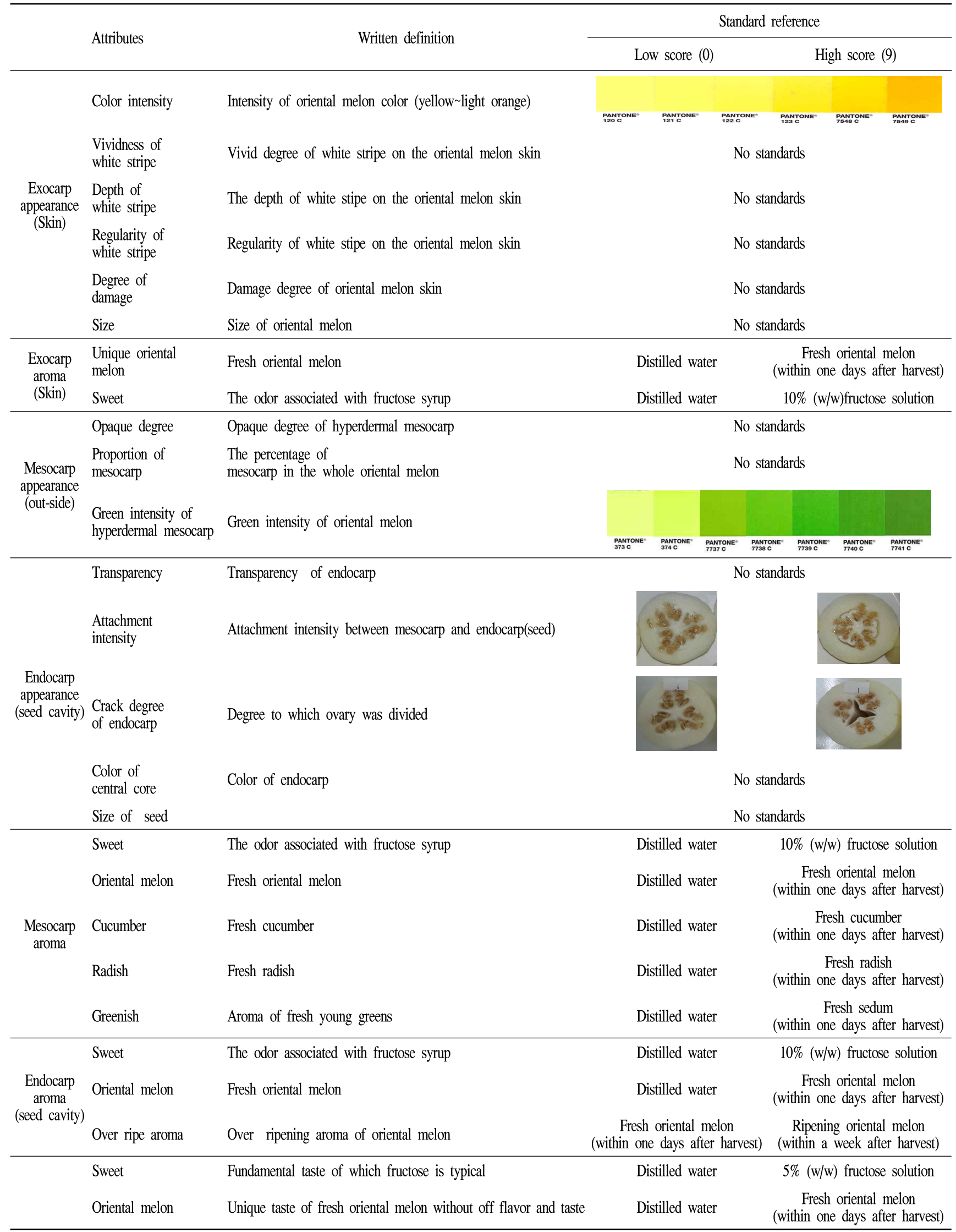




\begin{tabular}{|c|c|c|c|c|}
\hline & \multirow{2}{*}{ Attributes } & \multirow{2}{*}{ Written definition } & \multicolumn{2}{|c|}{ Standard reference } \\
\hline & & & Low score $(0)$ & High score (9) \\
\hline \multirow{5}{*}{$\begin{array}{c}\text { Mesocarp } \\
+ \\
\text { endocarp } \\
\text { Taste }\end{array}$} & Bitter & Fundamental taste of which caffeine is typical & Distilled water & $5 \%(w / w)$ caffeine solution \\
\hline & Cucumber & Unique taste of fresh cucumber without off flavor and taste & Distilled water & $\begin{array}{l}\text { Fresh cucumber } \\
\text { (within one days after harvest) }\end{array}$ \\
\hline & Sour & Fundamental taste of citric acid & Distilled water & $0.2 \%(\mathrm{w} / \mathrm{w})$ citric acid solution \\
\hline & Over ripe Taste & Fundamental taste of which alchol is typical & Distilled water & $5 \%(\mathrm{w} / \mathrm{w})$ alcohol solution \\
\hline & Greenish & Fresh young greens, fresh sedum & Distilled water & $\begin{array}{l}\text { Fresh sedum } \\
\text { (within one days after harvest) }\end{array}$ \\
\hline \multirow{3}{*}{$\begin{array}{c}\text { Mesocarp } \\
+ \\
\text { endocarp }\end{array}$} & Hardness & Force required to chew sample between molar teeth & \multicolumn{2}{|c|}{ No standards } \\
\hline & Juiciness & The amount of juice extracted to chew the sample( 4 times) & \multicolumn{2}{|c|}{ No standards } \\
\hline & Crunchjness & $\begin{array}{l}\text { Force needed and sound generated from chewing a sample with } \\
\text { the front teeth }\end{array}$ & \multicolumn{2}{|c|}{ No standards } \\
\hline \multirow{3}{*}{ Texture } & Seed content & The amount of seeds in the ovary & \multicolumn{2}{|c|}{ No standards } \\
\hline & Hardness of seed & Hardness intensity of seed & \multicolumn{2}{|c|}{ No standards } \\
\hline & Mealiness & Such as floury sensation in the mouse after chewing & \multicolumn{2}{|c|}{ No standards } \\
\hline \multirow{3}{*}{$\begin{array}{c}\text { Mesocarp } \\
+ \\
\text { endocarp }\end{array}$} & Sweet & Fundamental taste of which fructose is typical & Distilled water & $5 \%(\mathrm{w} / \mathrm{w})$ fructose solution \\
\hline & Astringency & Fundamental taste of tannic acid & Distilled water & $0.2 \%(\mathrm{w} / \mathrm{w})$ tannic acid solution \\
\hline & Sour & Fundamental taste of citric acid & Distilled water & $0.2 \%(\mathrm{w} / \mathrm{w})$ citric acid solution \\
\hline after taste & Acridity & Fundamental taste of close to the bitter and astringency & Distilled water & cinnamon powder \\
\hline
\end{tabular}

이가 없었고, $5.61 \pm 0.32 ~ 5.74 \pm 0.19$ 를 나타낸 반면 산 함량 은 유기농 시료는 $0.18 \pm 0.02 \sim 0.22 \pm 0.03 \%$ 였고, 관행 재배 시료는 $0.16 \pm 0.02 \%$ 로 관행 재배 시료가 약간 낮은 값을 보였다. 가용성 고형분 함량의 경우도 관행 재배 시료가 $13.20 \pm 0.72{ }^{\circ} \mathrm{Brix}$ 로 유기농 재배 시료 $10.36 \pm 0.30 \sim 11.46$ $\pm 0.84{ }^{\circ} \mathrm{Brix}$ 에 비하여 약간 높은 값이었다. 이는 Jang 등(15) 의 영양성분에는 문제가 없으나 표면 균열 및 과육 부부에
물이 찬 형태의 저급 참외의 경우 $\mathrm{pH} 5.39 \pm 0.03$, 산도 $0.32 \pm 0.09$, 가용성 고형분 함량 $11.00{ }^{\circ} \mathrm{Brix}$ 와 비교하여 본 실험에 사용한 참외의 경우 약간 높은 $\mathrm{pH}$ 와 낮은 산함량이 었으나, 가용성 고형분 함량의 경우에는 비슷한 값을 보였 다. 한편 동일 지역에서 유기농으로 재배된 참외와 관행 재배한 참외의 묘산 분석 중 껍질이 있는 참외의 외관과 향을 묘사분석에 의해 관능 특성을 외과피, 내과피 및 중과

Table 2. Quality properties and sensory evaluation of whole oriental melon with skin

\begin{tabular}{|c|c|c|c|c|c|c|c|c|}
\hline \multirow{2}{*}{\multicolumn{3}{|c|}{ Quality properties and sensory attribute }} & \multicolumn{6}{|c|}{ Whole oriental melon ${ }^{1)}$} \\
\hline & & & $\mathrm{OCI}$ & OCII & OCIII & OCVI & $\mathrm{OCV}$ & $\mathrm{CC}$ \\
\hline \multirow{4}{*}{\multicolumn{2}{|c|}{$\begin{array}{c}\text { Quality } \\
\text { properties }\end{array}$}} & Weight (g) & $256.66 \pm 23.12^{(2)}$ & $335.60 \pm 19.93^{\mathrm{a}}$ & $313.58 \pm 31.85^{\mathrm{ab}}$ & $291.12 \pm 19.35^{b}$ & $309.38 \pm 11.16^{\mathrm{ab}}$ & $283.48 \pm 9.58^{\mathrm{b}}$ \\
\hline & & $\mathrm{pH}$ & $5.73 \pm 0.05^{\mathrm{a}}$ & $5.74 \pm 0.19^{\mathrm{a}}$ & $5.57 \pm 0.05^{\mathrm{a}}$ & $5.61 \pm 0.32^{\mathrm{a}}$ & $5.61 \pm 0.32^{\mathrm{a}}$ & $5.68 \pm 0.07^{\mathrm{a}}$ \\
\hline & & Titratable acidity $(\%)$ & $0.22 \pm 0.03^{\mathrm{a}}$ & $0.19 \pm 0.04^{\mathrm{ab}}$ & $0.21 \pm 0.01^{\mathrm{a}}$ & $0.18 \pm 0.02^{\mathrm{ab}}$ & $0.21 \pm 0,02^{\mathrm{a}}$ & $0.16 \pm 0.02^{\mathrm{b}}$ \\
\hline & & Soluble solid contents (\%) & $11.28 \pm 0.81^{\mathrm{b}}$ & $10.70 \pm 0.39^{\mathrm{bc}}$ & $10.36 \pm 0.30^{\mathrm{bc}}$ & $11.16 \pm 1.03^{b}$ & $11.46 \pm 0.84^{\mathrm{b}}$ & $13.20 \pm 0.72^{\mathrm{a}}$ \\
\hline \multirow{8}{*}{$\begin{array}{l}\text { Whole } \\
\text { oriental } \\
\text { melon }\end{array}$} & \multirow{6}{*}{ Appearance } & Color intensity & $3.10 \pm 1.37^{\mathrm{e}}$ & $3.12 \pm 1.38^{\mathrm{e}}$ & $5.78 \pm 1.37^{\mathrm{c}}$ & $4.48 \pm 1.68^{\mathrm{d}}$ & $6.70 \pm 1.18^{\mathrm{b}}$ & $7.73 \pm 0.86^{\mathrm{a}}$ \\
\hline & & Glossness of white stripe & $6.60 \pm 1.75^{b}$ & $5.21 \pm 2.00^{\mathrm{c}}$ & $5.49 \pm 2.13^{\mathrm{c}}$ & $5.23 \pm 2.01^{\mathrm{c}}$ & $6.37 \pm 1.85^{\mathrm{b}}$ & $7.44 \pm 1.57^{\mathrm{a}}$ \\
\hline & & Depth of white stripe & $6.13 \pm 1.37^{\mathrm{a}}$ & $4.48 \pm 1.83^{\mathrm{c}}$ & $3.77 \pm 1.70^{\mathrm{e}}$ & $4.24 \pm 1.95^{\mathrm{de}}$ & $5.06 \pm 1.86^{b}$ & $5.91 \pm 1.79^{\mathrm{a}}$ \\
\hline & & Regularity of white stripe & $5.94 \pm 1.84^{\mathrm{bc}}$ & $5.81 \pm 1.91^{\mathrm{bc}}$ & $5.45 \pm 1.99^{c}$ & $5.32 \pm 1.95^{\mathrm{c}}$ & $6.17 \pm 1.81^{\mathrm{ab}}$ & $6.71 \pm 1.84^{\mathrm{a}}$ \\
\hline & & Degree of damage & $4.48 \pm 2.25^{\mathrm{a}}$ & $2.96 \pm 1.60^{\mathrm{cd}}$ & $3.95 \pm 2.25^{\mathrm{ab}}$ & $3.55 \pm 2.13^{\mathrm{bc}}$ & $2.91 \pm 1.85^{\mathrm{cd}}$ & $2.80 \pm 1.77^{\mathrm{d}}$ \\
\hline & & Size & $6.09 \pm 1.50^{b}$ & $6.67 \pm 1.35^{\mathrm{a}}$ & $5.66 \pm 1.59^{\mathrm{b}}$ & $3.70 \pm 1.55^{\mathrm{d}}$ & $5.07 \pm 1.83^{\mathrm{c}}$ & $6.05 \pm 1.03^{\mathrm{b}}$ \\
\hline & \multirow{2}{*}{ Aroma } & Unique oriental melon & $5.45 \pm 2.10^{\text {cd }}$ & $5.91 \pm 1.90^{\mathrm{bc}}$ & $5.24 \pm 1.95^{\mathrm{d}}$ & $5.77 \pm 1.96^{\text {bd }}$ & $6.27 \pm 1.69^{\mathrm{ab}}$ & $6.78 \pm 1.36^{\mathrm{a}}$ \\
\hline & & Sweet & $4.60 \pm 2.09^{\mathrm{cd}}$ & $5.13 \pm 2.08^{\mathrm{bc}}$ & $4.34 \pm 2.11^{\mathrm{d}}$ & $5.10 \pm 2.15^{\mathrm{bc}}$ & $5.59 \pm 1.98^{\mathrm{ab}}$ & $6.14 \pm 1.76^{\mathrm{a}}$ \\
\hline
\end{tabular}

${ }^{1)} \mathrm{OCI}-\mathrm{OCV}$, organic cultivation according to farm; $\mathrm{CC}$, conventional cultivation.

${ }^{2)}$ Means \pm SD within each column followed by the same letter are not significantly different $(p<0.05)$. 
피를 나누어 비교하였다. Table 2 는 외과피에 대한 평가로 참외 외관의 노란색 강도는 유기농 재배 참외 $3.10 \pm 1.37$ $6.70 \pm 1.18$, 관행 재배 $7.73 \pm 0.86$ 으로 관행재배 시료가 노란 색 강도가 높다고 평가하였고, 유기농 재배 참외는 관행재 배 시료보다 강도가 높다고 평가하였다. 참외 외관의 흰줄 의 선명도는 관행 재배 시료가 $7.44 \pm 1.57$ 로 가장 높게 평가 한 반면 유기농 재배 시료는 $5.21 \pm 2.00 ~ 6.60 \pm 1.75$ 의 점수로 평가하였다. 흰줄의 깊이는 유기농 재배 시료는 $3.77 \pm$ $1.70 ~ 6.13 \pm 1.37$, 관행 재배 시료는 $5.91 \pm 1.84$ 로 평가하였고, 흰줄의 균일성과 표면의 손상도의 경우 유기농 재배 시료는 각각 $5.32 \pm 1.95 \sim 6.17 \pm 1.81,2.91 \pm 1.85 \sim 4.48 \pm 2.25$, 관행재배 시료는 각각 $6.71 \pm 1.84,2.80 \pm 1.77$ 의 점수로 평가하였고, 참외 크기의 경우 재배 방법보다는 재배 농가별의 차이가 크다고 하였다. 참외의 고유한 향과 단향은 전반적으로 관 행재배 시료가 유기농 재배 시료보다 높은 점수로 평가하였 고, 유기농 시료 간에는 재배 농가별로 유의적인 차이가 있었다. 이는 Crecente-Campo 등(26)의 유기농 재배한 딸기 와 관행 재배한 딸기의 표면 광택도, 붉은색을 나타내는 $\mathrm{a}$ 값, 황색도를 나타내는 $\mathrm{b}$ 값과 채도 등이 관행 재배 시료가 유기농 재배 시료보다 높다고 평가한 결과와 유사하였다. 또 유의적인 차이는 없지만 당근의 주황색, 브로콜리의 초 록색의 경우 관행 재배 시료가 유기농 재배 시료보다 색강 도가 높다는 결과와 토마토의 경우 관행재배 시료가 유기농 재배 시료보다 붉은색 강도가 유의적으로 높았다는 결과 (27)와 유사하였다. Table 3은 중과피와 내과피의 관능적 묘사 특성에 의한 평가로 외과피 쪽의 중과피(hyperdermal mesocarp)의 불투명 정도는 관행재배 시료(CC)가 유기농 재배 시료(OCI OCV) $5.80 \pm 2.07 \sim 6.32 \pm 2.16$ 범위보다 약간 높은 $6.62 \pm 1.70$ 의 점수로 평가하였다. 중과피가 차지하는 비율은 유기농과 관행 재배와 상관없는 5.25 $\pm 1.51 \sim 5.96$ \pm 1.45 의 점수로 평가하였다. 또 외과피 가까운 쪽의 중과피 (hyperdermal mesocarp)의 초록색 강도는 유기농 재배 시료 인 $\mathrm{OFI}$ 시료를 제외하고는 유의적인 차이가 없는 4.59 $\pm 1.89 \sim 4.96 \pm 2.13$ 로 평가하였다. 한편 씨가 포함되어 있는 내과피의 외관이 경우 투명도는 재배 방법에 차이가 없다고 평가하였고 내과피와 중과피의 부착 강도는 재배 방법에 차이가 $\mathrm{OFII}$ 는 $4.84 \pm 2.13, \mathrm{OFVI}$ 는 $5.75 \pm 1.96, \mathrm{OCI}, \mathrm{OCIII}$, $\mathrm{OCV}$ 와 $\mathrm{CC}$ 는 각각 $6.74 \pm 1.89,6.73 \pm 1.71,7.03 \pm 1.74$ 및 $6.77 \pm 1.64$ 로 평가하였다. 재배 방법에 상관없이 전반적으 로 내과피의 갈라짐 정도 적다고 평가한 경우 씨가 있는 내과피 중앙 부분의 색이 진하고, 씨의 크기가 크다고 평가 하였다. 중과피의 향의 경우 단향과 참외향이 강하다고 평 가한 시료는 오이향과 무향 및 풋내가 적다고 평가하였고, 반면에 단향이 참외향이 약간 경우 반대로 평가를 하였다. 씨가 포함되어 있는 내과피의 단향과 참외향은 시료간 차이 가 없다고 평가하였고, 숙성된 참외향은 관행으로 재배한 시료가 가장 높은 $5.53 \pm 2.26$ 의 점수로 평가하였다. 씨 부분
이 포함된 내과피를 포함한 중과피의 맛의 경우 단맛과 참외 고유한 맛이 높은 시료는 오이맛과 덜익은 풋맛이 적다고 평가하였고, 신맛과 쓴맛은 시료간 차이가 없었다. 중과피 조직감의 경우 관행 재배는 다즙성과 아삭함이 있 고, 씨의 함량이 적으면서 씨의 경도가 낮다고 평가하였다. 또 후미의 경우 단맛, 떫은맛, 신맛, 쓴맛은 시료 간 거의 차이가 없다고 평가하였다. 이는 Tobin 등(27)의 유기농과 관행 재배 과채류 10 종을 훈련된 패널원으로 도출된 관능 특성을 평가한 결과 조리하지 않은 당근의 경우 주황색 강도와 조직감의 경도는 관행 재배가 유기농 재배 시료보다 강하고, 당근향, 수분함, 아삭함, 단맛, 쓴맛에는 차이가 없 다고 하였다. 또 사과의 경우 경도와 단맛은 관행재배 시료 가 유기농 재배 시료가 높으나, 사과향, 다즙성, 신맛, 사과 맛에는 유의적인 차이가 없다고 하였고, 바나나와 오렌지 의 경우 각 과일에 도출된 특성 항목(색, 향, 경도, 단맛, 신맛 등)에 유기농과 관행 재배 시료 간에 거의 차이가 없다고 평가하였다. 이외에 Hajslova 등(28)의 4년간 감자를 유기농과 관행 재배하면서 품질 특성을 조사한 결과 동일 재배 년도에도 차이를 보인 시료이지만, 재배년도나 재배 지역 차이에 따라 품질 특성이 달라진다고 하였다. 본 연구 결과도 일부 관능 특성 항목은 재배 방법에 따라 차이를 보인 특성 항목도 있으나, 동일 지역이라도 재배 농가나 시료의 개체 차이가 커서 유기농 재배 시료와 관행재배의 차이 특성을 확실하게 보이지 않았다.

정량적 묘사분석에 사용한 유기농 재배 참외 5 종과 관행 재배 참외 1 종을 수집하여 일반 소비자 100 명을 대상으로 소비자 검사를 실시하였다(Table 4). 그 결과 껍질이 붙어 있는 참외의 크기는 OCVI와 OCV가 $6.50 \pm 1.39,6.49 \pm 1.64$ 로 다른 시료보다 크다고 평가를 하였다. 참외 껍질의 노란 색 강도는 묘사 분석 결과 시료에 따라 $3.10 \pm 1.37$ 에서 $7.73 \pm 0.86$ 까지 넓은 분포의 점수로 평가한 반면 소비자 검 사에서는 $2.89 \pm 1.54$ 에서 $4.68 \pm 2.02$ 까지 점수 분포가 낮게 평가를 하였다. 표면의 손상 정도는 관행 재배 시료와 유기 농 재배 시료 중 $\mathrm{OCI}$ 시료가 가장 손상도가 높다고 평가하 여 묘사 분석 결과와는 다른 평가를 하였다. 참외의 중과피 의 두께는 관행 재배 시료가 가장 높은 점수인 $7.04 \pm 1.28$ 로 평가하였고, 유기농 재배 시료는 $4.68 \pm 1.62 \sim 5.54 \pm 1.62$ 의 범 위로 평가하였다. 내과피와 중과피의 부착 강도는 관행재 배 시료와 유기농 재배 시료 중 $\mathrm{OCV}$ 시료를 비슷한 점수로 평가하였다. 내과피의 씨 크기는 관행재배 시료가 가장 높 은 점수로 평가하였고, 유기농 재배 시료는 시료간 차이가 없다고 묘사 분석 결과와 동일하게 평가하였다. 중과피의 단향의 경우 시료간 차이가 없다고 평가한 묘사 분석과 달리 소비자 검사에서는 OCI과 OCVI가 다른 시료에 비해 높은 점수로 평가하였다. 참외향은 재배 방법에 상관없이 시료 간에 차이가 있다고 평가하였고, 과숙한 향의 경우는 시료간 차이가 없다고 평가하였다. 한편 중과피의 단맛은 
Table 3. Sensory evaluation of oriental melon mesocarp by qualitative descriptive analysis

\begin{tabular}{|c|c|c|c|c|c|c|c|}
\hline & \multirow{2}{*}{ Sensory attribute } & \multicolumn{6}{|c|}{ Oriental melon ${ }^{1)}$} \\
\hline & & OCI & OCII & OCIII & OCVI & $\mathrm{OCV}$ & $\mathrm{CC}$ \\
\hline \multirow{3}{*}{$\begin{array}{l}\text { Hyperdermal- } \\
\text { Mesocarp and } \\
\text { Mesocarp } \\
\text { appearance }\end{array}$} & Opaque degree & $6.32 \pm 2.16^{\mathrm{ab2} 2)}$ & $5.99 \pm 1.94^{\mathrm{ab}}$ & $5.95 \pm 1.83^{\mathrm{ab}}$ & $5.87 \pm 1.88^{\mathrm{ab}}$ & $5.80 \pm 2.07^{\mathrm{ab}}$ & $6.62 \pm 1.70^{\mathrm{a}}$ \\
\hline & Proportion of mesocarp & $5.77 \pm 1.48^{\mathrm{a}}$ & $5.94 \pm 1.33^{\mathrm{a}}$ & $5.25 \pm 1.38^{\mathrm{a}}$ & $5.52 \pm 1.51^{\mathrm{a}}$ & $5.28 \pm 1.45^{\mathrm{a}}$ & $5.96 \pm 1.45^{\mathrm{a}}$ \\
\hline & Green intensity & $6.63 \pm 1.75^{\mathrm{a}}$ & $4.59 \pm 1.89^{b}$ & $4.70 \pm 1.98^{\mathrm{b}}$ & $4.91 \pm 2.13^{\mathrm{b}}$ & $4.96 \pm 2.02^{\mathrm{b}}$ & $4.75 \pm 1.75^{\mathrm{b}}$ \\
\hline \multirow{5}{*}{$\begin{array}{l}\text { Endocarp } \\
\text { appearance } \\
\text { (seed cavity) }\end{array}$} & Transparency & $5.28 \pm 2.32^{\mathrm{a}}$ & $5.42 \pm 2.32^{a}$ & $5.55 \pm 2.05^{\mathrm{a}}$ & $5.41 \pm 2.08^{\mathrm{a}}$ & $5.73 \pm 2.16^{\mathrm{a}}$ & $4.98 \pm 2.39^{\mathrm{a}}$ \\
\hline & Attachment intensity & $6.74 \pm 1.89^{\mathrm{a}}$ & $4.84 \pm 2.13^{\mathrm{c}}$ & $6.73 \pm 1.71^{\mathrm{a}}$ & $5.75 \pm 1.96^{b}$ & $7.03 \pm 1.74^{\mathrm{a}}$ & $6.77 \pm 1.64^{\mathrm{a}}$ \\
\hline & Crack degree of endocarp & $2.31 \pm 1.57^{\mathrm{d}}$ & $3.75 \pm 2.66^{\mathrm{c}}$ & $5.34 \pm 2.73^{\mathrm{b}}$ & $3.62 \pm 2.50^{c}$ & $6.38 \pm 2.61^{\mathrm{a}}$ & $5.37 \pm 2.97^{b}$ \\
\hline & Color of central core & $7.55 \pm 1.00^{\mathrm{a}}$ & $6.71 \pm 1.56^{\mathrm{b}}$ & $4.41 \pm 1.77^{\mathrm{d}}$ & $6.88 \pm 1.19^{b}$ & $5.03 \pm 1.72^{\mathrm{c}}$ & $2.32 \pm 1.26^{\mathrm{e}}$ \\
\hline & Size of seed & $7.23 \pm 1.19^{\mathrm{a}}$ & $6.10 \pm 1.62^{b}$ & $4.31 \pm 1.91^{\mathrm{c}}$ & $6.56 \pm 1.40^{b}$ & $4.35 \pm 1.81^{\mathrm{c}}$ & $3.37 \pm 1.48^{\mathrm{d}}$ \\
\hline \multirow{5}{*}{ Mesocarp aroma } & Sweet & $5.14 \pm 2.23^{\mathrm{b}}$ & $5.82 \pm 1.93^{\mathrm{a}}$ & $6.02 \pm 1.82^{\mathrm{a}}$ & $6.05 \pm 1.81^{a}$ & $6.10 \pm 1.94^{\mathrm{a}}$ & $6.49 \pm 1.70^{\mathrm{a}}$ \\
\hline & Unique oriental melon & $6.24 \pm 2.06^{\mathrm{a}}$ & $6.24 \pm 1.90^{\mathrm{a}}$ & $6.13 \pm 1.75^{\mathrm{a}}$ & $6.35 \pm 1.83^{\mathrm{a}}$ & $6.46 \pm 1.80^{\mathrm{a}}$ & $6.59 \pm 1.76^{\mathrm{a}}$ \\
\hline & ${ }^{a}$ Cucumber & $4.75 \pm 2.20^{\mathrm{a}}$ & $4.34 \pm 2.17^{\mathrm{a}}$ & $3.98 \pm 2.23^{\mathrm{ab}}$ & $4.17 \pm 2.26^{\mathrm{a}}$ & $4.00 \pm 2.13^{\mathrm{ab}}$ & $3.32 \pm 1.92^{\mathrm{b}}$ \\
\hline & Radish & $4.77 \pm 2.29^{\mathrm{a}}$ & $3.66 \pm 2.01^{b}$ & $3.17 \pm 1.72^{b}$ & $3.74 \pm 2.01^{\mathrm{b}}$ & $3.06 \pm 1.70^{b}$ & $3.37 \pm 2.04^{\mathrm{b}}$ \\
\hline & greenish & $3.53 \pm 2.01^{\mathrm{a}}$ & $2.69 \pm 1.58^{b}$ & $2.42 \pm 1.25^{\mathrm{b}}$ & $2.64 \pm 1.51^{b}$ & $2.48 \pm 1.41^{\mathrm{b}}$ & $2.31 \pm 1.19^{b}$ \\
\hline \multirow{3}{*}{$\begin{array}{l}\text { Endocarp aroma } \\
\text { (seed cavity) }\end{array}$} & Sweet & $6.12 \pm 1.72^{a}$ & $6.67 \pm 1.44^{a}$ & $6.59 \pm 1.64^{\mathrm{a}}$ & $6.45 \pm 1.76^{\mathrm{a}}$ & $6.44 \pm 1.65^{\mathrm{a}}$ & $6.71 \pm 1.64^{a}$ \\
\hline & Unique oriental melon & $6.31 \pm 1.64^{\mathrm{a}}$ & $6.84 \pm 1.51^{\mathrm{a}}$ & $6.57 \pm 1.60^{\mathrm{a}}$ & $6.71 \pm 1.60^{\mathrm{a}}$ & $6.66 \pm 1.73^{\mathrm{a}}$ & $6.57 \pm 1.75^{\mathrm{a}}$ \\
\hline & Over ripening oriental melon & $3.91 \pm 2.05^{\mathrm{ab}}$ & $4.19 \pm 2.27^{b}$ & $4.13 \pm 2.34^{b}$ & $4.14 \pm 2.44^{b}$ & $3.88 \pm 2.32^{\mathrm{ab}}$ & $5.53 \pm 2.26^{\mathrm{a}}$ \\
\hline \multirow{7}{*}{$\begin{array}{l}\text { Mesocarp } \\
\text { taste }\end{array}$} & Sweet & $5.66 \pm 1.69^{\mathrm{bc}}$ & $6.28 \pm 1.65^{\mathrm{a}}$ & $5.39 \pm 1.66^{\mathrm{c}}$ & $6.12 \pm 1.60^{\mathrm{ab}}$ & $6.37 \pm 1.69^{\mathrm{a}}$ & $6.55 \pm 1.59^{\mathrm{a}}$ \\
\hline & Unique oriental melon & $5.53 \pm 1.85^{\mathrm{bc}}$ & $6.13 \pm 1.77^{\mathrm{ab}}$ & $5.46 \pm 2.03^{\mathrm{c}}$ & $6.16 \pm 1.68^{\mathrm{ab}}$ & $6.42 \pm 1.85^{\mathrm{a}}$ & $5.89 \pm 1.82^{\mathrm{abc}}$ \\
\hline & Bitterness & $2.87 \pm 1.76^{\mathrm{a}}$ & $2.53 \pm 1.54^{\mathrm{a}}$ & $2.60 \pm 1.63^{\mathrm{a}}$ & $2.69 \pm 1.64^{\mathrm{a}}$ & $2.35 \pm 1.31^{\mathrm{a}}$ & $2.67 \pm 1.83^{\mathrm{a}}$ \\
\hline & Cucumber & $4.14 \pm 1.90^{\mathrm{a}}$ & $3.16 \pm 1.80^{\mathrm{c}}$ & $3.87 \pm 1.88^{\mathrm{ab}}$ & $3.44 \pm 1.90^{\mathrm{bc}}$ & $3.50 \pm 2.04^{\mathrm{ab}}$ & $3.25 \pm 1.86^{\mathrm{bc}}$ \\
\hline & Sourness & $2.57 \pm 1.50^{\mathrm{a}}$ & $2.56 \pm 1.65^{\mathrm{a}}$ & $3.12 \pm 2.03^{\mathrm{a}}$ & $3.05 \pm 1.76^{\mathrm{a}}$ & $2.74 \pm 1.75^{\mathrm{a}}$ & $2.99 \pm 1.96^{\mathrm{a}}$ \\
\hline & Over ripe & $3.50 \pm 1.96^{\mathrm{bc}}$ & $3.69 \pm 2.31^{\mathrm{bc}}$ & $2.99 \pm 1.72^{\mathrm{c}}$ & $3.85 \pm 2.09^{b}$ & $3.25 \pm 1.96^{\mathrm{bc}}$ & $5.21 \pm 2.41^{\mathrm{a}}$ \\
\hline & Greenish & $3.14 \pm 1.88^{\mathrm{a}}$ & $2.24 \pm 1.35^{\mathrm{c}}$ & $2.87 \pm 1.72^{\mathrm{ab}}$ & $2.56 \pm 1.53^{\mathrm{bc}}$ & $2.52 \pm 1.40^{\mathrm{bc}}$ & $2.06 \pm 1.10^{\mathrm{c}}$ \\
\hline \multirow{6}{*}{$\begin{array}{l}\text { Mesocarp and } \\
\text { endocarp } \\
\text { texture }\end{array}$} & Hardness & $5.92 \pm 1.48^{\mathrm{ab}}$ & $5.39 \pm 1.57^{\mathrm{c}}$ & $5.82 \pm 1.39^{\mathrm{abc}}$ & $5.48 \pm 1.30^{\mathrm{bc}}$ & $6.09 \pm 1.48^{\mathrm{a}}$ & $5.96 \pm 1.47^{\mathrm{ab}}$ \\
\hline & Juiciness & $5.52 \pm 1.67^{\mathrm{b}}$ & $6.38 \pm 1.64^{\mathrm{a}}$ & $5.57 \pm 1.72^{\mathrm{b}}$ & $6.39 \pm 1.42^{\mathrm{a}}$ & $6.24 \pm 1.52^{\mathrm{a}}$ & $6.07 \pm 1.78^{\mathrm{ab}}$ \\
\hline & Crunchy & $6.21 \pm 1.61^{\mathrm{a}}$ & $5.87 \pm 1.61^{\mathrm{a}}$ & $5.75 \pm 1.67^{\mathrm{a}}$ & $5.85 \pm 1.41^{\mathrm{a}}$ & $6.20 \pm 1.59^{\mathrm{a}}$ & $6.34 \pm 1.55^{\mathrm{a}}$ \\
\hline & Content of seed & $6.28 \pm 1.73^{\mathrm{a}}$ & $5.46 \pm 1.77^{\mathrm{bc}}$ & $4.94 \pm 1.70^{\text {cd }}$ & $5.98 \pm 1.56^{\mathrm{ab}}$ & $5.39 \pm 1.82^{\mathrm{bc}}$ & $4.62 \pm 2.09^{\mathrm{d}}$ \\
\hline & Hardness of seed & $6.37 \pm 1.57^{\mathrm{a}}$ & $5.39 \pm 1.87^{\mathrm{b}}$ & $3.82 \pm 1.58^{\mathrm{c}}$ & $5.84 \pm 1.90^{\mathrm{ab}}$ & $4.23 \pm 1.74^{\mathrm{c}}$ & $3.12 \pm 1.82^{\mathrm{d}}$ \\
\hline & Mealiness of mesocarp & $3.16 \pm 1.51^{\mathrm{ab}}$ & $3.24 \pm 1.72^{\mathrm{ab}}$ & $3.62 \pm 1.85^{\mathrm{a}}$ & $2.88 \pm 1.46^{b}$ & $2.89 \pm 1.53^{\mathrm{b}}$ & $2.89 \pm 1.61^{b}$ \\
\hline \multirow{4}{*}{ After taste } & Sweet & $4.67 \pm 2.17^{\mathrm{ab}}$ & $5.37 \pm 2.30^{\mathrm{a}}$ & $4.32 \pm 2.22^{b}$ & $5.03 \pm 2.18^{\mathrm{ab}}$ & $5.32 \pm 2.22^{\mathrm{a}}$ & $5.35 \pm 2.36^{\mathrm{a}}$ \\
\hline & Astringency & $2.92 \pm 1.75^{\mathrm{a}}$ & $2.70 \pm 1.51^{\mathrm{a}}$ & $3.09 \pm 1.82^{\mathrm{a}}$ & $2.70 \pm 1.60^{\mathrm{a}}$ & $2.57 \pm 1.57^{\mathrm{a}}$ & $2.52 \pm 1.53^{\mathrm{a}}$ \\
\hline & Sour & $2.57 \pm 1.46^{\mathrm{a}}$ & $2.34 \pm 1.27^{\mathrm{a}}$ & $2.66 \pm 1.54^{\mathrm{a}}$ & $2.74 \pm 1.52^{\mathrm{a}}$ & $2.59 \pm 1.54^{\mathrm{a}}$ & $2.71 \pm 1.30^{\mathrm{a}}$ \\
\hline & Acridity & $3.34 \pm 1.95^{\mathrm{a}}$ & $2.88 \pm 1.84^{\mathrm{a}}$ & $3.07 \pm 1.94^{\mathrm{a}}$ & $2.95 \pm 1.80^{\mathrm{a}}$ & $2.71 \pm 1.70^{\mathrm{a}}$ & $2.89 \pm 1.85^{\mathrm{a}}$ \\
\hline
\end{tabular}

${ }^{1)}$ OCI-OCV, organic cultivation according to farm; $\mathrm{CC}$, conventional cultivation.

${ }^{2)}$ Means \pm SD within each column followed by the same letter are not significantly different $(p<0.05)$.

관행재배가 유기농 재배 참외보다 강하다는 평가와 달리 소비자 검사에서는 유기농 재배 시료중 OCVI이 가장 높은 점수로 평가되었다. 고유한 참외맛, 쓴맛, 과숙된 이미는 시료간 차이가 없다고 평가되었고, 경도, 다즙성, 아삭함의 경우 재배 방법보다는 시료에 따라 차이가 있다고 평가하였 고, 중과피의 씨의 함량과 씨의 강도는 묘사 분석과 유사하
게 관행 재배 시료가 유기농 재배 시료보다 씨 함량이 적고 씨의 단단한 정도가 낮다고 평가하였다. 이들 특성의 포함 하여 평가한 전반적인 기호도의 경우 가장 높은 기호도 점도 점수를 보인 시료는 유기농 재배 시료인 $\mathrm{OCVI}$ 였고, 가장 낮은 평가 점수를 나타낸 시료는 유기농 재배 시료인 OCIII이었다. 이 결과는 유기농 시료의 관능특성 항목에 
Table 4. Sensory evaluation of oriental melon by consumer

\begin{tabular}{|c|c|c|c|c|c|c|c|c|}
\hline \multirow{2}{*}{\multicolumn{3}{|c|}{ Sensory attribute }} & \multicolumn{6}{|c|}{ Oriental melon ${ }^{1)}$} \\
\hline & & & $\mathrm{OCI}$ & OCII & OCIII & OCVI & OCV & $\mathrm{CC}$ \\
\hline \multirow{3}{*}{\multicolumn{2}{|c|}{$\begin{array}{c}\text { Whole oriental melon } \\
\text { with skin }\end{array}$}} & Size & $5.46 \pm 1.63^{b 2)}$ & $4.22 \pm 1.83^{\mathrm{d}}$ & $4.97 \pm 1.82^{\mathrm{c}}$ & $6.50 \pm 1.39^{\mathrm{a}}$ & $6.49 \pm 1.64^{\mathrm{a}}$ & $5.91 \pm 1.73^{b}$ \\
\hline & & Color intensity & $4.68 \pm 2.02^{\mathrm{a}}$ & $2.89 \pm 1.54^{\mathrm{e}}$ & $3.85 \pm 1.95^{\mathrm{c}}$ & $4.03 \pm 2.10^{c}$ & $3.55 \pm 2.11^{\mathrm{b}}$ & $3.95 \pm 1.88^{\mathrm{b}}$ \\
\hline & & Degree of damage & $6.10 \pm 1.50^{b}$ & $2.95 \pm 1.38^{\mathrm{e}}$ & $5.08 \pm 1.50^{c}$ & $5.32 \pm 1.34^{\mathrm{c}}$ & $3.92 \pm 1.64^{\mathrm{d}}$ & $6.71 \pm 1.31^{\mathrm{a}}$ \\
\hline \multirow{17}{*}{ Mesocarp } & \multirow{3}{*}{ Appearance } & Width of mesocarp & $4.83 \pm 1.54^{\text {cd }}$ & $4.68 \pm 1.62^{d}$ & $5.54 \pm 1.62^{\mathrm{bc}}$ & $5.17 \pm 1.51^{\mathrm{bc}}$ & $5.27 \pm 1.47^{\mathrm{bc}}$ & $7.04 \pm 1.28^{\mathrm{a}}$ \\
\hline & & Attachment intensity ${ }^{3)}$ & $5.50 \pm 2.00^{c}$ & $5.40 \pm 1.96^{\mathrm{c}}$ & $5.80 \pm 2.02^{\mathrm{bc}}$ & $5.69 \pm 2.00^{\mathrm{c}}$ & $6.40 \pm 1.95^{\mathrm{a}}$ & $6.31 \pm 2.00^{\mathrm{ab}}$ \\
\hline & & Size of seed & $5.84 \pm 1.41^{\mathrm{a}}$ & $5.78 \pm 1.57^{\mathrm{a}}$ & $5.67 \pm 1.69^{\mathrm{a}}$ & $5.75 \pm 1.50^{\mathrm{a}}$ & $5.57 \pm 1.70^{\mathrm{a}}$ & $3.09 \pm 1.29^{\mathrm{b}}$ \\
\hline & \multirow{3}{*}{ Aroma } & Sweet & $6.11 \pm 1.83^{\mathrm{ab}}$ & $5.56 \pm 1.81^{\mathrm{bc}}$ & $5.61 \pm 2.02^{\mathrm{bc}}$ & $6.24 \pm 1.50^{\mathrm{a}}$ & $5.49 \pm 1.85^{\mathrm{c}}$ & $5.80 \pm 1.93^{\mathrm{abc}}$ \\
\hline & & Unique oriental melon & $6.01 \pm 1.52^{\mathrm{a}}$ & $5.92 \pm 1.76^{\mathrm{a}}$ & $6.05 \pm 1.97^{\mathrm{a}}$ & $6.58 \pm 1.29^{\mathrm{a}}$ & $5.85 \pm 1.83^{\mathrm{a}}$ & $6.15 \pm 1.82^{\mathrm{a}}$ \\
\hline & & Over ripe aroma & $2.66 \pm 1.81^{\mathrm{a}}$ & $2.72 \pm 1.65^{\mathrm{a}}$ & $2.67 \pm 1.73^{\mathrm{a}}$ & $2.43 \pm 1.61^{\mathrm{a}}$ & $2.64 \pm 1.60^{\mathrm{a}}$ & $2.71 \pm 1.76^{\mathrm{a}}$ \\
\hline & \multirow{4}{*}{ Taste } & Sweet & $6.02 \pm 1.77^{\mathrm{ab}}$ & $6.00 \pm 2.09^{\mathrm{ab}}$ & $5.01 \pm 1.98^{\mathrm{c}}$ & $6.38 \pm 1.68^{\mathrm{a}}$ & $5.47 \pm 2.18^{\mathrm{bc}}$ & $5.82 \pm 1.96^{\mathrm{ab}}$ \\
\hline & & Unique oriental melon & $5.90 \pm 1.79^{b}$ & $5.77 \pm 1.81^{\mathrm{b}}$ & $5.54 \pm 1.93^{\mathrm{b}}$ & $6.43 \pm 1.59^{\mathrm{a}}$ & $5.73 \pm 1.91^{\mathrm{b}}$ & $5.77 \pm 1.86^{b}$ \\
\hline & & Bitterness & $2.46 \pm 1.64^{\mathrm{a}}$ & $2.85 \pm 1.84^{\mathrm{a}}$ & $2.86 \pm 1.76^{\mathrm{a}}$ & $2.51 \pm 1.48^{\mathrm{a}}$ & $2.63 \pm 1.48^{\mathrm{a}}$ & $2.80 \pm 1.85^{\mathrm{a}}$ \\
\hline & & Over ripe taste (off flavor) & $2.87 \pm 1.92^{\mathrm{ab}}$ & $3.34 \pm 2.19^{\mathrm{a}}$ & $3.13 \pm 1.90^{\mathrm{ab}}$ & $2.59 \pm 1.59^{b}$ & $3.22 \pm 2.00^{\mathrm{a}}$ & $3.40 \pm 2.02^{\mathrm{a}}$ \\
\hline & \multirow{6}{*}{ Texture } & Hardness & $4.51 \pm 1.79^{b}$ & $4.39 \pm 1.73^{b}$ & $5.45 \pm 1.85^{\mathrm{a}}$ & $5.47 \pm 1.52^{\mathrm{a}}$ & $5.48 \pm 1.76^{\mathrm{a}}$ & $5.32 \pm 1.83^{\mathrm{a}}$ \\
\hline & & Juiciness & $6.03 \pm 1.65^{\mathrm{ab}}$ & $5.99 \pm 1.70^{\mathrm{ab}}$ & $5.72 \pm 1.66^{b}$ & $6.01 \pm 1.67^{\mathrm{ab}}$ & $6.08 \pm 1.52^{\mathrm{ab}}$ & $6.25 \pm 1.62^{\mathrm{a}}$ \\
\hline & & Crunchy & $4.73 \pm 1.91^{b}$ & $4.56 \pm 1.98^{b}$ & $5.94 \pm 1.93^{\mathrm{a}}$ & $5.88 \pm 1.75^{\mathrm{a}}$ & $5.85 \pm 1.82^{\mathrm{a}}$ & $5.68 \pm 2.06^{\mathrm{a}}$ \\
\hline & & Seed content & $5.70 \pm 1.68^{\mathrm{a}}$ & $5.79 \pm 1.71^{\mathrm{a}}$ & $6.04 \pm 1.63^{\mathrm{a}}$ & $6.02 \pm 1.61^{a}$ & $5.56 \pm 1.76^{\mathrm{a}}$ & $4.76 \pm 1.90^{\mathrm{b}}$ \\
\hline & & Hardness of seed & $4.90 \pm 1.88^{\mathrm{a}}$ & $5.30 \pm 1.90^{\mathrm{a}}$ & $5.30 \pm 1.74^{\mathrm{a}}$ & $5.28 \pm 1.67^{\mathrm{a}}$ & $4.38 \pm 1.82^{\mathrm{b}}$ & $3.05 \pm 1.41^{\mathrm{c}}$ \\
\hline & & Mealiness & $4.28 \pm 1.91^{\mathrm{a}}$ & $4.14 \pm 1.82^{\mathrm{ab}}$ & $3.95 \pm 1.89^{\mathrm{ab}}$ & $3.63 \pm 1.57^{\mathrm{b}}$ & $3.67 \pm 1.63^{\mathrm{b}}$ & $3.83 \pm 1.78^{\mathrm{ab}}$ \\
\hline & \multicolumn{2}{|c|}{ Total acceptability } & $5.63 \pm 1.70^{b}$ & $5.18 \pm 1.90^{\mathrm{bc}}$ & $4.98 \pm 1.94^{\mathrm{d}}$ & $6.14 \pm 1.52^{\mathrm{a}}$ & $5.22 \pm 1.97^{\mathrm{bc}}$ & $5.38 \pm 1.95^{\mathrm{bc}}$ \\
\hline
\end{tabular}

${ }^{1)} \mathrm{OCI}-\mathrm{OCV}$, organic cultivation according to farm; $\mathrm{CC}$, conventional cultivation.

${ }^{2)}$ Means \pm SD within each column followed by the same letter are not significantly different $(p<0.05)$.

${ }^{3)}$ Attachment intensity between mesocarp and endocarp (seed).

따라 차이가 있는 것도 있으나, 재배 지역, 재배 년도에 따라 차이가 있다는 결과 $(27,29)$ 와 유기농 재배와 관행재배 한 채소류의 소비자 100 명으로 양상추, 시금치, 토마토, 오 이, 양파 등을 조사한 결과 일부 관능 특성 항목에는 차이가 있었으나, 전체적인 기호도에는 큰 차이가 없었다는 결과 와 동일하였다.

\section{참외 품질 특성 주성분 분석}

묘사분석에 의한 재배 방법별 참외의 품질과 관능적 품 질 중 외관 특성의 주성분 분석(principal component analysis) 결과는 Fig. 1과 같다. 첫 번째 주성분(F1)과 두 번째 주성분 $(\mathrm{F} 2)$ 는 전체 데이터의 $42,43 \%$ 와 $15.93 \%$ 의 설명 력을 보여 주었고, 총설명력은 $58.36 \%$ 였다. 주성분 $\mathrm{F} 1$ 왼편 으로 표면의 손상정도, 총산도, 무게를 제외하고 재배 농가, 재배 방법, 광택도, 참외 껍질의 흰줄 깊이 등의 특성들은 $\mathrm{F} 1$ 의 오른편에 위치하였고 가용성 고형분 함량, 참외 고유 의 향, 단향 등이 비슷한 위치에 있어 상관성이 높은 것을 알 수 있었다. 한편 재배 방법 및 농가별 수집된 참외 시료의 경우 OCI OCIII 시료는 좌표상 왼편에 OCV시료와 CC 시 료는 좌표상 오른편에 분포하였다. 또 각 농가별 시료군은
몇몇 시료를 제외하고 비슷한 위치에 분포하였고 시료간 이화학적 및 관능적 품질 특성에 차이가 있는 것을 알 수 있었다. 한편 Fig. 2는 재배 농가 및 재배 방법별 참외의 중과피와 내과피의 품질 특성과 이들 시료의 이화학적 특성 의 포함하여 주성분 분석을 실시한 결과이다. 껍질이 제거 된 참외의 중과피와 내과피 특성중 첫 번째 주성분(F1)과 두 번째 주성분(F2)는 전체 데이터의 $26.65 \%$ 와 $19.53 \%$ 의 설명력을 보여 주었고, 총설명력은 $46.18 \%$ 로 참외의 외관 의 설명력과 비교하여 낮았다. 주성분 $\mathrm{F} 1$ 은 재배 농가, 재배 방법, 총산도, 내과피 씨 부분의 갈라짐 정도, 오이향, 무향, 단향, 쓴맛 등 많은 특성이 있었고, F2 요인으로는 색, 과숙 된 내과피의 향, 중과피의 신맛, 씨 함량, 씨의 경도였다. 주성분 F1 오른쪽의 위쪽으로 중과피의 풋향, 무향, 오이향 과 신맛, 쓴맛, 오이맛, 중과피 외부의 초록색 강도, 중과피 조직감 중 가루끼가 위치하였고, 이들 특성과 반대되는 특 성은 왼쪽 좌표의 아래 부분에 중과피와 내과피의 씨 부분 의 부착강도, 중과피의 외부의 투명도, 중과피의 다즙성이 위치하여 한쪽 부분의 특성이 강하면 반대 위치의 특성이 약하다는 것을 확인할 수 있었다. 또 참외의 중과피 및 내과 피의 이화학적 특성인 가용성 고형분 함량과 참외향과 단향 

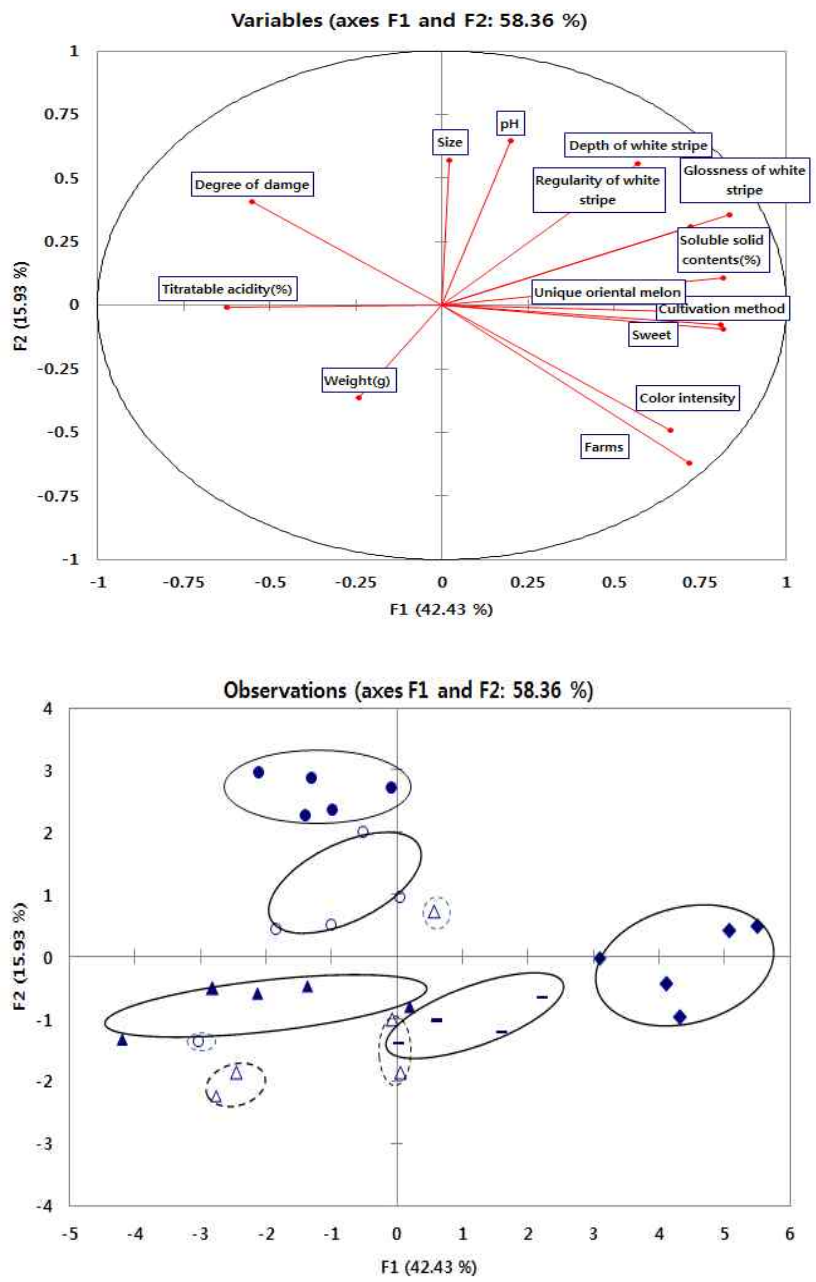

Fig. 1. Principal component analysis of quality properties and sensory attributes of whole oriental melon with skin by quantitative descriptive analysis.

○, OCI; O, OCII; $\mathbf{\Delta}$, OCIII; $\triangle$, OCV; -, OCV; $\diamond, \mathrm{CC}$; OC, organic cultivation; $\mathrm{CC}$, conventional cultivation.

과 가까이 위치하였고, 반대의 위치인 F1 오른쪽의 아래쪽 에 씨의 경도, 씨 함량, 내과피 중심의 색이 위치하였다. 또 재배 방법 및 농가별 수집된 참외 시료의 중과피와 내과 피의 품질 특성의 분포도를 보면 $\mathrm{OCI}$ 시료는 좌표상 오른편 에 $\mathrm{CC}$ 시료를 제외하고는 중첩되어 중앙부분에 분포하였 다. 즉 과피가 포함된 참외 시료의 경우는 외관에 의해 농가 별 시료간 차이가 있었으나, 과피가 제거된 중과피와 내과 피의 관능특성 항목에서는 관행재배(CC)를 제외하고는 농 가별 시료는 확실하게 구분되지 않았다.

한편 일반 소비자 대상으로 묘사분석에서 사용한 동일한 참외를 대상으로 소비자 검사를 실시한 후 관능적 품질 특성의 주성분 분석(principal component analysis)을 실시하 였다(Fig. 3). 첫 번째 주성분(F1)과 두 번째 주성분(F2)는 전체 데이터의 $29.21 \%$ 와 $22.69 \%$ 의 설명력을 보여 주었고, 총설명력은 $51.90 \%$ 였다. $\mathrm{F} 1$ 요인은 조직감 중 경도, 아삭함,
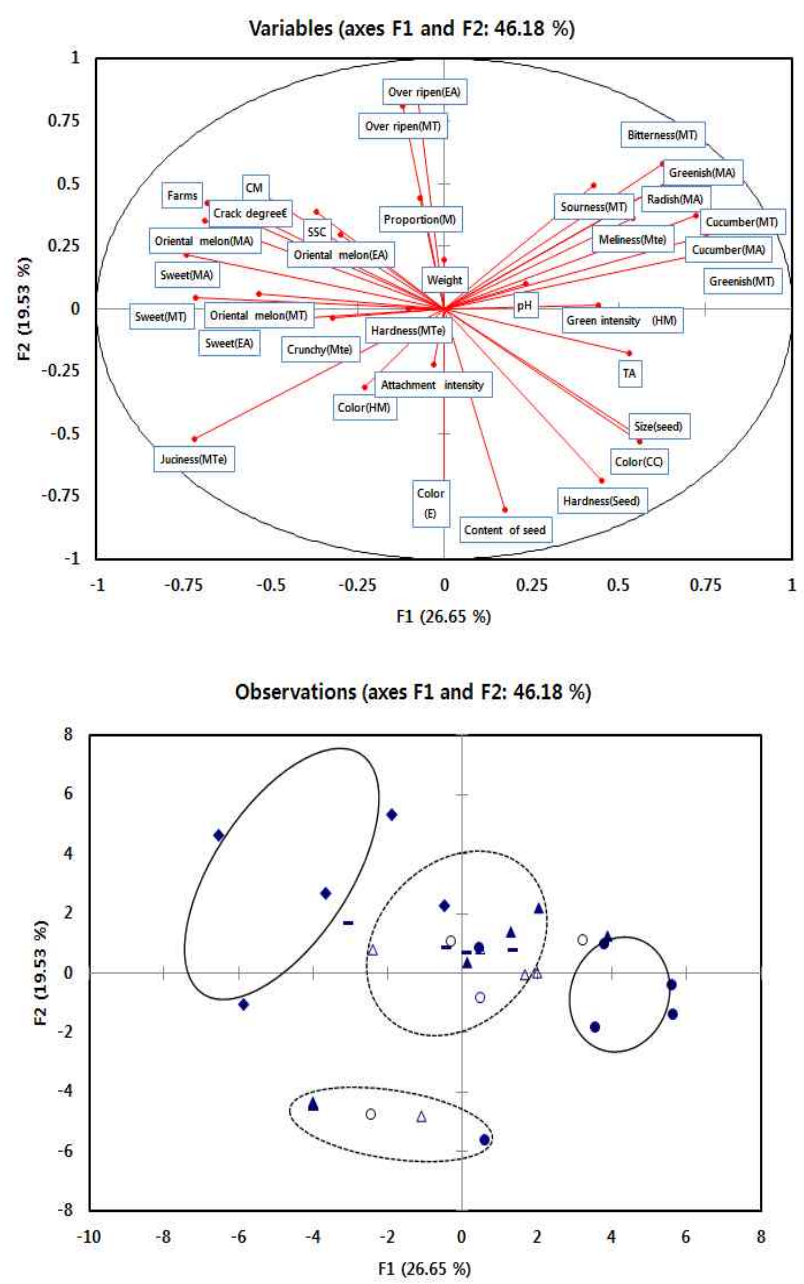

Fig. 2. Principal component analysis of sensory attributes in the mesocarp and endocarp of oriental melon by quantitative descriptive analysis.

, OCI; O, OCII $\boldsymbol{\Delta}$, OCIII; $\triangle$, OCVI; -, OCV; $\diamond, \mathrm{CC}$; OC, organic cultivation; $\mathrm{CC}$, conventional cultivation.

MA, mesocarp aroma; MT, mesocarp taste; MTe, mesocarp texture; EA, endocarp aroma; $\mathrm{CC}$, control core.

참외의 단향, 참외의 표면 손상도, 내과피의 씨 부분의 부착 정도였고, F2요인은 중과피의 두께, 씨의 크기, 단맛, 씨 함량으로 묘사분석의 결과와 달리 소비자 조사에서 참외의 조직감이 중요한 요인으로 분석되었다. 전반적인 기호도와 관련된 관능특성항목으로는 단맛, 단향, 참외고유의 향과 맛이 가장 큰 영향이 있었고, 참외 껍질의 색, 아삭함, 다즙 성, 경도도 기호도 점수가 높은 것과 영향이 있었다. 반면에 쓴맛, 과숙된 향, 과숙된 맛, 가루끼는 좌표상 반대에 위치하 여 이들 특성이 많으면 전반적인 기호도가 낮아지는 것을 확인할 수 있었다.

이상의 결과에서 참외 시료에 따른 관능특성의 정량적 묘사 분석과 전반적읜 기호도를 포함한 소비자 조사 결과, 동일 지역의 동일 품종으로 재배된 유기농 재배 참외와 관행 재배 참외 시료는 전반적으로 재배 방법의 차이도 
있지만, 재배 농가와 시료의 개체에 따라 차이가 있다고 분석되었다. 최근 유기농 재배 참외에 대한 소비자의 관심 도가 급증하고 있고, 실제 소비자가 원하는 참외의 품질 지표를 알고 유기농 재배와 관행 재배시의 참외의 차이를 확실히 알아 문제점을 개선하고 생산 농가에서는 고품질 참외 생산에 노력이 필요하다고 여겨진다. 본 연구결과는 2015년산 성주지역에서 유기농 재배 참외 농가에서 수집된 일부 시료로만 연구가 진행된 것으로 더 많은 유기농 재배 시료와 관행 재배 시료와의 품질 차이에 대한 연구가 되어 야 한다고 여겨진다.

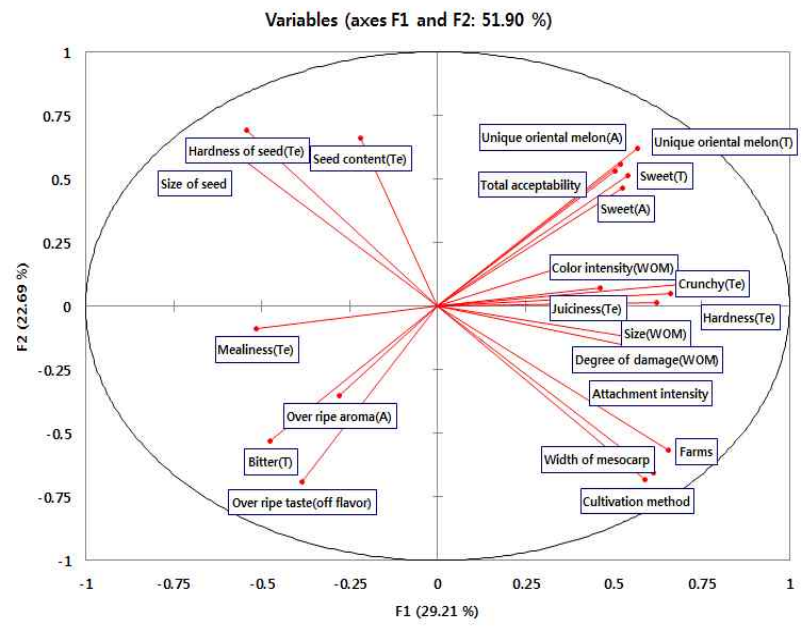

Observations (axes F1 and F2: $51.90 \%$ )

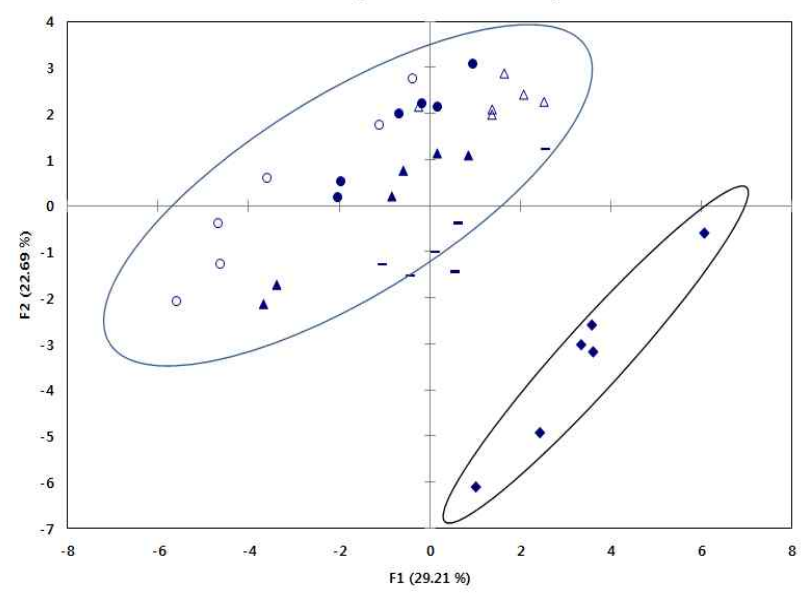

Fig. 3. Principal component analysis of sensory attributes of oriental melon by consumer test.

, OCI; O, OCII; $\mathbf{\Lambda}$, OCIII; $\triangle$, OCVI; -, OCV; $\diamond$, CC; OC, organic cultivation; $\mathrm{CC}$, conventional cultivation.

MA, mesocarp aroma; MT, mesocarp taste; MTe, mesocarp texture; EA, endocarp aroma; $\mathrm{CC}$, control core.

\section{요 약}

본 연구는 친환경 참외의 품질 등급 설정을 위한 기초
자료 제공을 위하여 성주지역에서 재배되는 참외의 묘사적 관능 특성 개발과 재배 방법별 품질 지표의 품질 특성을 조사하였다. 성주산 참외의 묘사분석 결과 총 40 개가 도출 되었는데, 외과피에서 도출된 특성 6 종과 향 특성 2 종 및 중과피의 외관 특성 3종, 내과피 (endocarp) 외관 특성 4종, 또 중과피의 향 특성 5 종과 내과피의 씨부분의 특성 3 종이 도출되었다. 이외에 중과피의 맛 7 종 및 조직감 특성 6 종이 었다. 한편 유기농 재배와 관행 재배된 참외의 $\mathrm{pH}$, 총산도, 고형분 함량 등이 전반적으로 재배 방법과 재배 농가에 따라 유의적인 차이를 보였다. 또 이들 시료를 대상으로 묘사 분석 및 일반 소비자 대상으로 관능검사를 실시한 결과 전반적으로 관행재배 시료와 유기농 재배 시료 간에 차이가 있었고, 재배 농가별로 차이가 있다고 분석되었다. 묘사분석에 의한 외관특성과 참외 중과피와 내과피의 품질 특성들의 주성분 분석결과 첫 번째 주성분(F1)과 두 번째 주성분(F2)에 의한 총설명력은 각각 $58.36 \%, 46.18 \%$ 였다. 전반적으로 과피가 포함된 참외 시료의 경우는 외관에 의해 재배 방법과 재배 농가별로 비교적 차이가 뚜렷하였으나, 과피가 제거된 중과피와 내과피의 관능특성 항목에서는 관행재배(CC)를 제외하고는 농가별 시료는 확실하게 구분 되지 않았다. 한편 소비자 조사 후 관능적 품질 특성의 주성 분 분석 결과가 묘사 분석 결과와 유사하였고, 전체적인 기호도와 관련이 있는 관능적 품질 특성은 단맛, 단향, 참외 고유의 향과 맛, 참외 껍질의 노란색, 아삭함, 다즙성, 경도 가 중요한 영향 요인이었다.

\section{감사의 글}

본 연구는 농림축산식품부·농림수산식품기술기획평가 원 고부가가치식품기술개발사업의 연구비 지원으로 수행 되었으며, 이에 감사드립니다.

\section{References}

1. Yi SI, Kwon YS, Bae KM, Song IH (2004) Recent porgresses for the variety classification and denomination of oriental melon and melon (Cucumis melo L.). Korea J Hort Sci Technol, 22, 515-522

2. Jang SJ, Jo YJ, Seo JH, Kim OM, Jeong YJ (2014) Enzyme treatment for clarification of spoiled oriental melon juice. J Korean Food Preserv, 21, 506-511

3. Jo YJ, Jang SY, Kim OM, Park CM, Jeong YJ (2010) Effects of sugars addition in alcohol fermentation of oriental melon. Korean J Soc Food Sci Nutr, 39, 1359-1365

4. Kim KC (2002) Changes of physiological by abnormal 
fermentation of 'Gumssaragi' melon fruit. MS Thesis, Chungnam National University, Korea

5. Kim CS, Lee SH (2009) The comparison analysis between consumers and dealers' willingness to purchase environmentally friendly agricultural products. Korean J Organic Agriculture, 17, 291-306

6. Jin HJ, Keum SH (2011) The effects of price on consumers' purchasing behavior for eco-friendly foods. Korean J Marketing Research, 16, 105-133

7. Ahn JW, Jeon YH, Hwang J, Kim HY, Kim JH, Chung DH, Kim JE (2012) Monitoring of pesticide residues and risk assessment for fruit vegetables and root vegetables of environment-friendly certified and general agricultural products. Korean J Environ Agric, 31, 164-169

8. Choi DW, Kim TK (2014) An analysis on productivity change in environment-friendly farming of fruit vegetables. Korean J Organic Agri, 22, 335-345

9. Cha SK, Chun HI, Hong SS, Kim WJ, Koo YJ (1993) Manufacture of fermented cantaloupe melon with lactic starter culture. Korean J Food Sci Technol, 25, 386-390

10. Zhang MF, Li ZL (2005) A comparison of sugaraccumulating patterns and relative composition in developing fruits of two oriental melon varieties as determined by HPLC. Food Chemistry, 90, 785-790

11. Lee GD, Kim SK, Lee MH (2005) Quality change of beverage containing muskmelon vinegar and concentrated muskmelon juice during storage. Korean J Food Preserv, 12, 223-229

12. Lee GD, Kwon SH, Lee MH, Kim SK (2004) Change of organoleptic properties with heating concentration of oriental melon juice. Korean J Food Preserv, 11, 130-133

13. Nam JH, Ahn JJ, Suh JK, Kim DW (2013) Quality characteristics of a kimchi containing oriental melon peel. Korean J Food Preserv, 20, 518-523

14. Kim OM, Jo YJ, Jeong YJ (2015) Quality characteristics of non oriental melon Makgeolli by adding sucralose. Korean J Food Preserv, 22, 377-384

15. Ko SB, Hyun CS (2010) Setting the citrus quality standards based on consumer preference survey. J Korea Academia-Indus cooperation Soc, Fall Conference Proceedings, 564-567

16. Park JD, Hong SI, Park HW, Kim DM (2000) Extending shelf-life of oriental melon (Cucumis melo L.) by modified atmosphere packaging. Korean J Food Sci Technol, 32, 481-490

17. Lee MY, Yoo MS, Whang YJ, Jin YJ, Hong MH, Pyo YH (2012) Vitamin C, total polyphenol, flavonoid contents and antioxidant capacity of several fruit peels. Korean J Food Sci Technol, 44, 540-544
18. Kim HS, Kang YH (2010) Antioxidant activity of ethanol extracts of non-edible parts (stalk, stem $\cdot$ leaf, seed) from oriental melon. Korean J Plant Res, 23, 451-457

19. Hwng HY, Ha HT, Ha SB, Seong GU, Hwang IW, Chung SK (2015) Quality characteristics and antioxidant capacities of oriental melon wine depending on pretreatments. Korean J Food Preserv, 22, 421-427

20. Ko SB, Hyun CS (2011) Setting in Korean mandarine quality standards based on consumer preference survey. J Korea Academia-Indus cooperation Soc, 12, 3430-3438

21. Ku KH, Lee KA, Choi JH (2015) Sensory properties of Satsuma mandarin by quantitative descriptive analysis. Korean J Food Preserv, 22, 241-250

22. AOAC (1996) Official method of analysis. 15th ed, Association of official analytical chemists, Washington DC, USA, p 607

23. Mailgarrd M, Civille G, Carr B (2007) Descriptive analysis techniques. Chapter 10. In: Sensory evaluation techniques, 4th ed, CRC Press, Taylor \& Francis Group, Boca Raton, FL, USA, p 173-186

24. Bett-Garber KL, Greene JL, Lamikanrao, Ingram DA, Watson MA (2011) Effect of storage temperature variations on sensory quality of fresh-cut cantaloupe melon. Journal of Food Quality, 34, 19-29

25. Vallone S, Sivertsen H, Anthon GE, Barrett DM, Mitcham EJ, Ebeler SE, Zakharov F (2013) An integrated approach for flavour quality evaluation in muskmelon (Cucumis melo L. reticulatus group) during ripening. Food Chem, 139, 171-183

26. Crecente-Campo J, Nunes-Dmaceno M, RomeroRodriguez MA, Vazquez-Oderiz ML (2012) Color, anthocyanin pigment, ascorbic acid and total phenolic compound determination in organic versus conventional strawberries. J Food Composition and Analysis, 28, 23-30

27. Tobin R, Moane S, Larkin T (2013) Sensory evaluation of organic and conventional fruits and vegetables available to Irish consumers. International $\mathrm{J}$ Food Sci Technol, 48, 157-162

28. Hajslova J, Schulzova V, Slanina, P, Janne K, Hellenas KE, Andersson CH (2007) Quality of organically and conventionally grown potatoes: Four-year study of micronutrients, metals, secondary metabolites, enzymic browning and organoleptic properties. Food Additives \& Contaminants, 22, 514-534

29. Zhao X, Chambers E, Matta Z, Loughin TM, Carey EE (2007) Consumer sensory analysis of organically and conventionally grown vegetables. J Food Sci, 72, 587-591 